\title{
Corrigendum: Lessons from human teratomas to guide development of safe stem cell therapies
}

J J Cunningham, T M Ulbright, M F Pera \& L H Looijenga

Nat. Biotechnol. 30, 849-857 (2012); published online 10 September 2012; corrected after print 4 June 2013

In the version of this article initially published, there were two errors in the discussion of epigenetic marks on page 854 . In sentence 4 , paragraph 2 of the section "Genetic and epigenetic changes predictive of malignancy," dimethylated and trimethylated H3K9 were said incorrectly to be "polycomb" marks. "Polycomb" has been deleted from the sentence, and the following two sentences inserted for clarification: "In ES cells these genes are held in a 'transcription ready' state by two marks, a repressive H3K27me mark and an active mark, H3K4me ${ }^{64}$. Changes in the balance of repressive versus active marks can alter the activity of these genes, hypothetically keeping cells in a proliferative state." Further down in the paragraph, DNMT3L

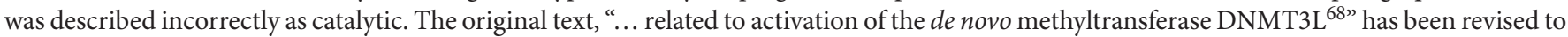
“... and maintain expression of the de novo methyltransferase-like protein DNMT3L ${ }^{68}$. Expression of DNMT3L appears to be a common feature in pluripotent cells including ES, EC and embryonic germ cells." The errors have been corrected in the HTML and PDF versions of the article.

\section{Corrigendum: Microparticles bearing encephalitogenic peptides induce T-cell tolerance and ameliorate experimental autoimmune encephalomyelitis.}

\author{
Daniel R Getts, Aaron J Martin, Derrick P McCarthy, Rachael L Terry, Zoe N Hunter, Woon Teck Yap, Meghann Teague Getts, \\ Michael Pleiss, Xunrong Luo, Nicholas J C King, Lonnie D Shea \& Stephen D Miller \\ Nat. Biotechnol. 30, 1217-1224 (2012); published online 18 November 2012; corrected after print 4 June 2013
}

In the version of this article initially published, the description of mice in the first paragraph of Online Methods was incomplete. Female SJL/J mice should have been described as SJL/JCrHsD; female BALB/c mice, as BALB/cJ mice; TCR transgenic mice expressing a TCR on the SJL/J background, expressed it on the SJL/JCrHsD background. $\mathrm{Marco}^{-/-}$mice, described as "on the BALB/c background," should have been described as backcrossed to the BALB/cAncrl (Charles River) background. The errors have been corrected in the HTML and PDF versions of the article.

\section{Corrigendum: Life sciences venture capital in emerging markets}

Justin Chakma, Stephen M Samut \& Ajay Agrawal

Nat. Biotechnol. 31, 195-201 (2013); published online 7 March 2013; corrected after print 30 April 2013

In the version of this article initially published, in Table 1, the number of health biotech firms, including those not backed by venture capital, in South Africa, was given as 78 in 2007. It should be 64 in 2010. The error has been corrected in the HTML and PDF versions of the article.

\section{Corrigendum: Giving voice to India's entrepreneurs}

\section{Gayatri Saberwal}

Nat. Biotechnol. 31, 104-107 (2013); published online 22 January, 2013; corrected after print 30 April 2013

In the version of this article initially published online, it was suggested that a $\$ 90,000$ grant would be used to cover salaries for 18 months. The grant is not restricted to salaries. The error has been corrected for the PDF and HTML versions of this article.

Corrigendum: Editors' pick: Orphazyme

\section{Ken Garber}

Nat. Biotechnol. 31, 189 (2013); published online 7 March 2013; corrected after print 4 June 2013

In the version of this article initially published, Steven Walkley's name was misspelled as Steven Walkely. The error has been corrected in the HTML and PDF versions of the article. 